\title{
Staying Relevant and Current with Online Learning in an Increasingly Global and Competitive Environment
}

\author{
http://dx.doi.org/10.3991/ijac.v5i3.2171 \\ Dr Grace Lynch and Rhys James \\ Open Universities Australia, Melbourne, Australia
}

\begin{abstract}
This paper outlines the success of online learning in the workplace with corporate partners through Open Universities Australia (OUA). OUA is recognized as the national leader in online higher education in Australia with over 200,000 students studying with OUA since 1993. The corporate program helps employees formalize or extend their current skills, reach the next level in their organization or pursue relevant interests through tertiary studies. The business sector sees OUA as a highly attractive solution to fostering a culture of professional development, engagement and inclusiveness.
\end{abstract}

Index Terms - corporate education, leader online learning.

\section{INTRODUCTION}

As Australia's national leader in online learning Open Universities Australia (OUA) is a consortium of 20 educational institutions and professional associations with over 200,000 students having studied since its inception in 1993.

In the United States the number of enrolled students taking at least one online course is growing at ten times the rate of the overall higher education population which is undoubtedly the reason that online teaching is seen as a core strategy for over 65\% of American Chief Academic Officers [1]. Students are demanding some component of their program delivered online whether it is one module, one subject, one unit or the complete degree. They wish to spend less time on campus and are demanding higher quality online engagement. The opportunities for online learning span across borders as students can enroll and study online regardless of where they live and or where the institution physically exists.

In Australia that growth pattern is similar with online enrolments growing by $29 \%$ compared to an on-campus growth rate of $5 \%$ in 2010 [2]. In Canada, while online enrolments are increasing the growth rate is slower than the US and Australia [3]. It is known that targets are being set to significantly increase the percentage of the population holding degree level qualifications. For example, the United States government has set a target of 58 to $60 \%$ of 25 to 34 year olds to hold a degree level qualification by 2020, up from 39\% in 2009 [4]. In Australia the government has set a more modest target of $40 \%$ but that is coming off a base of $29 \%$ in 2009. (See Fig. 1)

It is difficult to determine which factors have had the greatest impact and/or influence on the increased demand for online education. Whether it is:

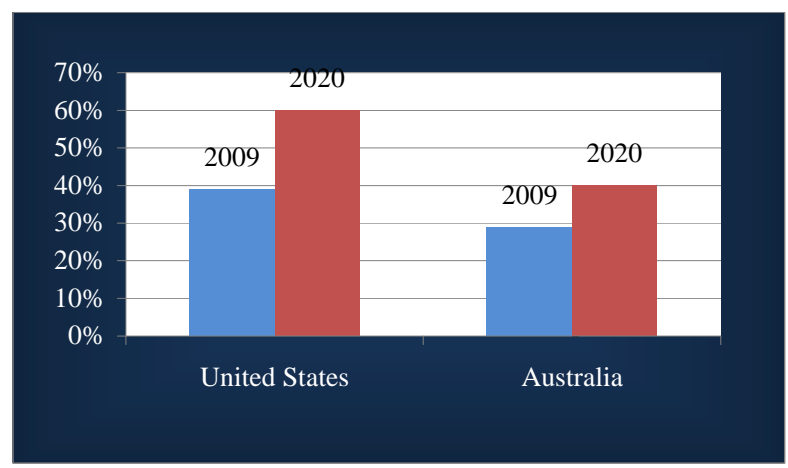

Figure 1. Percentage of 25-34 year olds with degree-level qualifications

- a global trend for a more educated society as productivity gains and technological advances reduce the need for skilled labor;

- difficult economic times which usually sees an increase in demand for education as the job market becomes more competitive, putting the onus on individuals to upskill and achieve higher levels of educational qualifications;

- advancements in technology that support online learning providing greater access, reliability, enhanced experiences and reduced costs; and/or

- improved quality and acceptance of online learning as legitimate as on campus study.

Regardless of factor the reality is that students are no longer constrained by an inflexible model of education where they must choose from a limited number of courses, to study at a particular time and place according to the institution and at a controlled pace.

In an increasingly global and competitive environment, staying relevant and current in the marketplace is important for both employees and employers. Fig.2 illustrates that over $50 \%$ of students are studying online due to work commitments while $30 \%$ prefer to study in an online mode [5]. Providing corporate clients with access to higher education can complement their retention strategies, improve employee productivity, strengthen their employee benefits portfolio and set them apart as an employer of choice. An educated and skilled workforce is required in this rapidly changing technological world. 


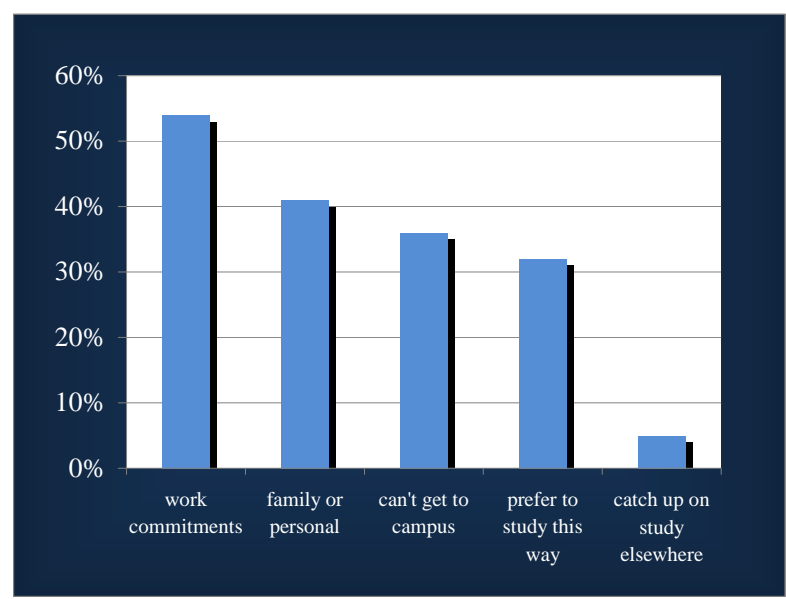

Figure 2. Reasons for Studying Online

\section{CORPORATE EDUCATION}

While the corporate initiative at OUA only started in 2010 there are at present over 30 corporate partners whose employees have access to more than 1800 units of study and 180 qualifications.

Current corporate and industry partners include: National Australia Bank, Australian Defence Force, Incitec Pivot, Victorian Automobile Chamber of Commerce, Publicis Solutions, Heinz, Choice Hotels Australasia, Baptcare, Westpac, Peoplebank Australia., IAG Asset Management, and Australian air Express.

A huge portion of OUA students are working adults looking for the liberty to study where and when it suits them. Through the corporate channel OUA extends the same advantage of convenience and flexibility to both employer and employee - developing the skills and knowledge they both need. The primary mission of corporate partnerships is to expand access to higher education in Australia to include under-represented groups, working adults as well as students in regional and remote areas.

The top programs for enrolments include arts, humanities and social sciences, business, education, health, information technology, law, and science.

As is evident in Table I, the corporate enrolment numbers increased 20\% from 2010 to 2011 and are on track to more than double in 2012 since the enrolments are already at half with three more enrolment periods to occur.

As an example, for one corporate partner, the National Bank of Australia (NAB) in 2011 had 103 employees enrolled in 210 units (courses). As of March 21 2012, OUA has already received a total of 170 enrolments from just 71 employees. This growth may in part be due to the seismic shift in terms of forecasted financial job losses over the next 2 years and it is obvious that staff are looking to either be retained or transitioned to alternative roles internally or failing that to new roles at other companies.

For OUA the corporate initiative reinforces the relevance of not only the units, but also the programs and partner universities. Furthermore it provides insight to inform and address the future needs of the industry. For industry a key benefit is retention and transition of staff for greater talent engagement and management.

As evidence for how the corporate initiative is gaining traction for OUA a recently displaced bank employee applied for a new role with one of the large insurance companies and after a positive interview was asked if he had any questions. The candidate asked the interviewer what they offered in the way of professional development opportunities as his previous employer had an arrangement with Open Universities Australia with some employee benefits attached. The interviewer asked "would that really get you over the line with the role?" to which the candidate replied "it would actually, my previous employer had a host of options in place and I was hoping you would have something similar." [6] Since then that company has become a corporate partner with OUA.

OUA students are very diverse with age ranges from 13 to 94 with the greatest concentration in the 25 to 39 age brackets. Table II illustrates the percentage distribution by age group for students in on campus traditional universities in Australia, OUA students and corporate students. The distribution is very even for corporate students and OUA. This is a huge market opportunity that the traditional universities are not flexible enough to capture hence the attraction for these age groups of online learning.

It is important to note that through OUA employees can attain a qualification from the university they study with that is identical to that awarded to an on-campus student. These internationally recognized units and courses give graduates a competitive edge in the marketplace. Online learning with four study periods each academic year enable employees to fast track their qualification. In addition there are no entry requirements for most undergraduate units so staff who went directly into the workforce from high school are not disadvantaged when they choose to return to study. Many employees are looking to formalize qualifications in areas in which they currently work or for roles they have grown into to cement their positions and employment status.

TABLE I.

CORPORATE AND INTERNATIONAL ENROLMENTS

\begin{tabular}{|l|c|c|c|}
\hline Enrolment Type & $\mathbf{2 0 1 0}$ & $\mathbf{2 0 1 1}$ & $\mathbf{2 0 1 2}^{*}$ \\
\hline Corporate & 1402 & 1682 & 840 \\
\hline International & 4447 & 4969 & 2251 \\
\hline Total & $\mathbf{5 8 4 9}$ & $\mathbf{6 6 5 1}$ & $\mathbf{3 0 9 1}$ \\
\hline
\end{tabular}

${ }^{\text {a }}$ Note this is only for first quarter with 3 more enrolment periods to go while others are for complete year enrolments.

TABLE II.

DISTRIBUTION BY AGE GROUP BY PERCENTAGE FOR 2011

\begin{tabular}{|l|c|c|c|}
\hline Age Group & University* & OUA & Corporate \\
\hline $18-24$ & 56 & 28 & 33 \\
\hline $25-29$ & 13 & 24 & 30 \\
\hline $30-39$ & 14 & 28 & 30 \\
\hline $40-49$ & 8 & 13 & 6 \\
\hline Others & 9 & 7 & 1 \\
\hline
\end{tabular}

a Note: this refers to students on campus in traditional universities 
Business clients can take advantage of special offers including:

- Priority enrolment

- Textbook vouchers

- Enrolment Advisors to match career aspirations with a study plan

- Student enrolment advice, counseling, library services, preparatory units and online tutorial support to help gain necessary academic skills such as writing, referencing, researching and critical thinking.

- No entry requirements for most undergraduate units

- Ideal higher-education solutions solution for geographically spread organizations

- Highly attractive government loan scheme for selffunded individuals

\section{CENTRE FOR ONLINE LEARNING EXCELLENCE}

The overarching challenge in this current climate is quality of the learning experiences for the students, the quality of staff and the quality of the courses. Any online organization is only going to survive and thrive if they offer the best courses, from the best institutions, supported by the best staff.

This flexibility of learning within a course or program is also being extended to a wider learning experience, with students mixing and matching on campus, online, intensive mode, etc. This places an additional challenge of maintaining quality across different modes and institutions. Students are taking increasing control over how and when they learn and institutions have to be flexible to move with the students' demands.

That is one driver for OUA in establishing the Centre for Online Learning Excellence (COLE) focusing on high quality learning engagement to improve student retention, satisfaction and progression. During the past three years OUA has experienced an annual enrolment growth in excess of $26 \%$, which is greater than the increase in the sector as a whole and greater than the global trend.

A recent US report prepared for the Department of Education reviewed more than a thousand empirical studies of online learning and "found that, on average, students in online learning conditions performed modestly better than those receiving face-to-face instruction.” [7] These results will be contentious for many academics but the fact is that online learning has and continues to gain credibility as an accepted and demanded mode of learning.

OUA has extended its reach into corporate education by leveraging off its success in the higher education online learning field.

\section{CONCLUSION}

Online education has enabled much greater participation and the trend will continue. Students who were previously unable or unlikely to take up tertiary education now have opportunities that were inconceivable not that long ago. Mid-career and people with significant work commitments, those with family responsibilities, those with disabilities and the many who live in regional and remote areas, areas that cannot sustain a physical higher education institution can now enroll in courses and programs from leading universities without major upheaval or disruption to their lives. The needs and demands for workplace learning is increasing and online education seems to have provide what both employers and employees are looking for.

\section{REFERENCES}

[1] I.E. Allen, J. Seaman, Going the Distance: Online Education in the United States, 2011.Babson Survey Research Group and Quahog Research Group, LLC, November 2011.

[2] DEEWR, 2010 Full year Student Summary Tables. http://www.deewr.gov.au/HigherEducation/Publications/HEStatist ics/Publications/Pages/2012StudentFullYear.aspx.

[3] Human Resources and Skills Development Canada, 2012, Online University Education in Canada: Challenges and Opportunities.

[4] U.S. Department of Education, Meeting the Nation's 2020 Goal: State Targets for Increasing the Number and Percentage of College Graduates with Degrees, Washington, D.C., 2011

[5] Open Universities Australia Student Satisfaction Survey Data, 2011.

[6] R.James, 2012, Private email communication.

[7] U.S. Department of Education, Office of Planning, Evaluation, and Policy Development, Evaluation of Evidence-Based Practices in Online Learning: A Meta-Analysis and Review of Online Learning Studies, Washington, D.C., 2010.

\section{AUTHORS}

Dr Grace Lynch is the Senior Project Manager for the Centre for Online Learning Excellence with Open Universities Australia, Melbourne, Australia. (e-mail: grace.lynch@open.edu.au).

Rhys James is the Corporate and International Manager with Open Universities Australia, Melbourne, Australia (e-mail: rhys.james@open.edu.au).

This article is an extended version of a paper presented at the conference ICELW2012, held June 2012, at Columbia University, in New York, NY, USA. Manuscript received 30 March 2012. Published as resubmitted by the authors 5 August 2012. 